\title{
Augustine and the Old Testament Eschatological Tradition: Personal History, Divine Retribution, and Sacrifice
}

\author{
By Dmitri Starostin*
}

\begin{abstract}
This study addresses the question of the correlation in the works of Saint Augustine and other scholars of his age of the sacred history, with its origin in the Old and New Testaments, and the personal, "individual time" of life path that was realized in their understanding of the concept of "today," even as biblical concepts of the end of times and of Apocalypse formed a fundamental background to these representations. These specialized concepts of time, with their clearly marked delineations between beginning and end, were a fundamental characteristic of Christianity, including ideas about the Incarnation, Resurrection, and of the Second Coming. As founding thinkers of the early Christian church, Jerome and Augustine helped set the foundation for all further representations of sacred history in Western Christianity until the end of the middle Ages. Recent studies suggest that Augustine left a self-contradictory heritage with respect to matters of explaining how the overarching biblical history could be applied as a model to the actual history of Rome. Moreover, Rome itself also boasted a long tradition of power and had its own scheme of defining the length of historical periods characterized by its own beginnings and ends for the multiple stages of development in the history of the Western Mediterranean. In this study I seek to explore a new reading of Augustine's take on Apocalypse. In my view, Augustine's experience of addressing the matters of the beginning and the end of times was rooted, as we see in the "Confessions", in his own experiences of the the father-son paradigm and was closely related in turn to one of the key elements of Christology, the idea of the sacrifice of the first-born son.
\end{abstract}

\section{Introduction: Augustine, Sacred History and Personal History}

One of the important issues of identification of a community in matters of religion and the sacred in general is the concept of historical time. The Christian calendar included several integrated systems of measuring time that had originated in the traditions of Egypt and Mesopotamia. The key element of Christian time, it was argued, was its "linearity". Christians differed from pagans in their belief that history had a clearly demarcated beginning and end of time. ${ }^{1}$ But a deeper investigation of how the Christin calendar was set raises the question of uncertainty in the matters of calendar and in particular to one of the unsolved problems that had been left from the debates about the meaning and structuring of the Christian time of history in the times of Jerome

\footnotetext{
*Assistant Professor, University of St-Petersburg, Russia.

1. Arnaldo Momigliano, "Pagan and Christian historiography in the fourth century A.D.," in Essays in Ancient and Modern Historiography, ed. Arnaldo Momigliano (Middletown, Conn.: Wesleyan University Press, 1977), 120-26.
} 
and Augustine. Specifically, matters of setting the Christian era and how to adjust the linear calendar of the Old Testament to the actual history of the Roman Empire in the late fourth and early fifth centuries were pressing concerns for the "doctor of the church" from Hippo. ${ }^{2}$ In fact, how Augustine reconciled his own quite successful life to the context of his own times and the upcoming "End of Times" was more difficult that it may at first appear. If the scheme of the time from the Creation was applied in his days, it predicted the end "now" and did not allow for any postponement. But this scheme significantly shifted the emphases in the representation of Apocalypse because it separated the "numerical" representations of the End of Times from the realities one could find in contemporary history. ${ }^{3}$ The tone in putting up the conceptual framework for the discussion of the time of history as part of the everyday ecclesiastical self-identification within the sacred calendar's scheme of time was set by Augustine, who argued that only biblical history allowed for an expositio and interpretation. He argued so because he believed that only in "secular" history, that of the Christian saeculum, God revealed himself to the humanity. ${ }^{4}$ The key element of Augustine's contribution was to seek to deter people from thinking in terms of the pre-set periods of time like the 3952 or 5199 as in the Hebrew Bible. Augustine was believed to have noticed John the Baptist's coming as failing all calendar predictions and most importantly, failing to bring the change that had been expected of him. Thus the bishop of Hippo argued for Apocalypse as a concept, but against using any kind of mathematical calculations to set the date of this very Apocalypse. ${ }^{5}$

Augustine emerged as part of the cohort of bishops who went the similar life path at the beginning of the fifth century and who moved in their exegesis from highly complex theological questions to matters related to setting the church life in the province where they had been assigned by the church hierarchy and the imperial court. Several cases highlight well the context in which Augustine existed, the pending tasks of creating a theology for "today" and the challenges of being an educated Christian in the context of political engagements expected by the imperial courts from the bishops. Christian

2. Johannes Van Oort, "The End Is Now: Augustine on History and Eschatology." HTS Teologiese Studies/Theological Studies 68, no. 1(2012): Art. \#1188.

3 Richard Landes, "The silenced millenium and the fall of Rome: Augustine and the year 6000 Am I," in Augustine and Apocalyptic and the Fall of Rome: Augustine and the Year 6000, ed. John Doody, Kari Kloos, and Kim Paffenroth (Lanham: Lexington Books, 2014), $169-71$.

4. Robert Austin Markus, Saeculum: history and society in the theology of St Augustine (Cambridge: Cambridge University Press, 1970), 1-21; Mayke De Jong, "The empire as ecclesia: Hrabanus Maurus and biblical historia for rulers," The Uses of the Past in the Early Middle Ages, ed. Yitzhak Hen and Matthew Innes (Cambridge: Cambridge University Press, 2000), 198.

5. Landes, "The Silenced Millenium," 168-70. 
authors like Tertullian, Clement of Alexandria, Origen, Jerome, Rufinus of Aquilea and John Cassian never rose above presbyter status. It happened because a bishop of a large city like Antioch would be charged with many practical tasks. ${ }^{6}$ Paulinus of Nola, having originated from a very aristocratic family, on the other hand, became advanced in the career of the bishop, leaving in his letters just hints of the educated concepts of time. ${ }^{7}$ Synesios of Cyrene, whose life as a native of Africa was very close to that of Augustine, followed a similar life path and the challenges an educated churchman faced while trying to combine theological musings at the court sojourn and the reality of a province facing the dismemberment of power. ${ }^{8}$ Augustine was thus only one of many bishops, but probably the only one from Africa, who managed to gain acceptance at the imperial court, who excelled in theoretical issues, and who later successfully faced the task of creating a life for himself in the present. But how to descend from the "eternal history" to the issues of life in the present? Synesius, for example, faced a number of tragedies, such as the death of his sons and his own declining health. Even Augustine found himself at times, ill-equipped to face the challenges of the real life in Late Antiquity.

Ever since the concept of the four empires and their earthly decay emerged, doctors of the church have asked questions about whether and how to draw the border in Augustine's writings between the usual time of human history, the saeculum, and God's eternal time. ${ }^{9}$ The apocalyptic exegesis and the adjustment the universal history schemes of the past to maintaining legitimacy of the contemporary elites originated in this context of personal challenges of the changing environment of the fifth century, which could be counted as that just few decades away from the coming of the millenial kingdom. The adaptation of the Old Testament history, and especially of the prophecies and the eschatology their authors professed, to the needs of Late Antique Roman society, took a number of forms. The use of the "four empires" narrative that may be found in the Book of Daniel placed the current history of the Roman Empire within the larger context and made rife the expectations of its possible end with the coming of the overbearing barbarian military groups.

6. Claudia Rapp, Holy Bishops in Late Antiquity: The Nature of Christian Leadership in an Age of Transition, Transformation of the Classical Heritage 37 (Berkeley: University of California Press, 2013), 181.

7. Ibid., 190.

8. Bernhard Bischoff and Michael M. Gorman, Manuscripts and Libraries in the Age of Charlemagne (Cambridge; New York: Cambridge University Press, 1994), 189, Rapp, Holy Bishops in Late Antiquity, 157-165.

9. Markus, Saeculum, 6. 
This Old Testament text was from the beginning of the spread of Christianity key to elevating the eschatological expectations of the end of the world. ${ }^{10}$

The commentaries on the Book of Daniel by Jerome were not a creation of an "apocalyptist hiding in a cave in a desert", but rather a work of an educated individual, well-integrated into the upscale networks of Near Eastern society, that promised a future rather than denied it. ${ }^{11}$ It has been argued that the chapters two and seven of the book of Daniel were used to question or uphold the existing social order. ${ }^{12}$ The commentaries of Jerome, written at the time when Rome most suffered from the barbarian pressures in the first and second decades of the fifth century, made discussing Rome's future and its much needed response to the demands of time a pressing need..$^{13}$ The comment Jerome gave to the verse 22 of chapter 2 is instructive about his attitude to the vagaries of the Roman empire's history and its predicament in the present. The verse: "And it is $\mathrm{He}$ who changes times and seasons, who transfers kingdoms and establishes kingdoms" he interpreted in the way that reminded of the eventual disintegration and fall of every known empire. He wrote: Let us not marvel, therefore, whenever we see kings and empires succeed one another, for it is by the will of God that they are governed, altered, and terminated. And the cases of individuals are well known to Him who founded all things. He often permits wicked kings to arise in order that they may in their wickedness punish the wicked. At the same time by indirect suggestion and general discussion he prepares the reader for the fact that the dream Nebuchadnezzar saw was concerned with the change and succession of empires. ${ }^{14}$

Augustine's views on the larger time scales of the Old Testament seem to have been categorized as the system of the two different parts: the belief in the six ages of the world and thus in the year 6000 from the Creation and the hints at the ways this scheme could be reconciled with the actual Roman calendar where no end of the world and the coming of Antichrist could be found in the everyday matters of describing the affairs of the church in the weakening Empire. At the crossroads between the time of the longue durée and the time of the fourth and fifth century Augustine positioned saeculum, the fluid and everchanging concept that in his system joined the earthly city and the divine

10. Lester L. Grabbe, "A Daniel for All Seasons," in The Book of Daniel: Composition and Reception, ed. John J. Collins, Peter W. Flint, and Cameron VanEpps (Leiden: Brill, 2002), 244.

11. Ibid., 243, 246.

12. McGinn, Visions of the End, 66-73.

13. Norman Perrin and Dennis C. Duling, The New Testament: An Introduction, Proclamation and Parenesis, Myth and History (San Diego: Harcourt Brace Jovanovich, 1974), 65-72, 76-79, 84; McGinn, Visions of the End, 22, 51-55, 66-73, 82-87.

14. Gleason L. Archer, Jerome's Commentary on Daniel, ed.\& transl. Gleason L. Archer (Eugene, Oregon: Wipf; Stock, 2009), 500. 
city. ${ }^{15}$ In his view both the sacred history and the secular history arose from the primal sin and produced the series calamitatis for humanity. Temporality itself was being created within the learned discourse of a historian or a theologian, but it fell short of history. Let us, however, disassemble and deconstruct the attempts to provide a synthetic view of the saeculum concept by pointing out at a number of problems of approaching this theme. Historicity, in turn, was the sign of the world in which there was nihil solidum, nihil stabile because the overarching scheme of the Christian history made theologians face the problems of reconciling the mathematical predictions with the actual scales of historical time of the Roman Republic and Empire. Thus even by looking at the higher and longer scales of time man still usually created historicity for himself within the uncertain parameters given to him by the people who had aspired to create a solemn representation of the past. ${ }^{16}$ Thus in various works Augustine proposed different versions of his reading of the problem of adapting the sacred time scale to the actual time scale. At the same time, I would argue, since we take different works, which might have had a different logic underlying them each time, we might find him confusing his readers with a sudden shift of the narrative, which reduced the possibilities for discerning the God's age from the human age. The citizen of the heavenly city was just as well part of the saeculum as was the citizen of the earthly city. ${ }^{17}$ In Augustine view saeculum was the sphere of temporal realities in which the two cities shared an interest. ${ }^{18}$ Thus it was a complex concept in which Augustine sought to promote unity rather than division of the two concepts of time. Thus the initial division between the God's time and the human time, even if this human had created a sacred history concept, remained critical because Augustine seemed to have found no solution to the problem of God and his 'time' existing anywhere near the disarray and disorder of the human course of history.

This approach to seeing Augustine as giving no uniform definition of saeculum and instead promoting this concept as an illustration of complexity of the issue rather than a definite response to the question has been recently updated in a series of studies. This study seek to address this question by seeking to find a possibility to connect the eschatological thinking to the life of Augustine himself and to find in his life the moment that we could designate as correlating to his eschatological thinking.

\footnotetext{
15. Van Oort, "The end is now."

16. Markus, Saeculum, 10-11.

17. Ibid., 102.

18. Ibid., 133.
} 


\section{Augustine and the Dilemma of Eternity and the Present}

After the loss of the battle of Adrianople in $378 \mathrm{CE}$ and thus in the times when the "End of Times" and the beginning of the "Millenial Kingdom" were ringing heavily in the heads of the educated Christian theologians, Augustine, as it was shown, became an anchor that tied the tradition of long-term predictions and the tradition of knowing the calendar day by day. The importance of rediscovering the future in light of the eschatological considerations that beset Jerome and Tyconius by Augustine has recently been shown to exceed earlier assessments. ${ }^{19}$ In discussing Augustine's contribution one thus needs to take into account the significant differences in the purpose of each text that addressed either a particular occasion or a particular question in the Christology and/or in the theology of time. The stance he took in the "Confessions" was that of a scholar who sought to construct a description of life within the context of the Biblical narrative. But on other occasions and in the works of the lesser genre his task was not to assemble the "history of life", but to disassemble it. In these smaller treatises, much as in the De duabus civitatibus he undertook a different task, to find structural elements in history and their conjunctions and overlaps. This was predicated on the need to tackle the history of Rome in a way that would let him fit it into the framework proposed by the Old Testament narrative. ${ }^{20}$

The representations of time one can find in the "Confessions" are to be kept aside, especially for the time of the discussion and before the ultimate synthesis of this inquiry, from the other thoughts and statements of him regarding the problem of the upcoming millenial kingdom. ${ }^{21}$ This is particularly warranted because of the considerable differences in rhetorics even within one treatise, the Confessiones, let alone the differences between this work, De duabus civitatibus and the large number of lesser treatises like De nocte and the sermons he published. ${ }^{22}$ Thus it has become a well-established fact that he lived within the eschatological world and yet argued for the importance of "today" as the concept that must be at the core of every Christian's thinking. ${ }^{23}$ But one needs to be aware that Augustine, both through

19. Richard Corradini, "Augustine's eschaton: Back to the Future," in Abendländische Apokalyptik. Kompendium zur Genealogie der Endzeit, ed. Veronika Wieser et al., Kulturgeschichte der Apokalyptik 1 (Berlin: Akademie Verlag Berlin, 2013), 693-713.

20. Landes, "The Silenced Millenium," 151-55.

21. Van Oort, "The End Is Now."

22. Augustine, "Confessiones," ed. J. J. O’Donnell (Oxford: Clarendon Press, 1992); Augustine, "Tractatus de nocte sancta," in Sermons pour la Pâque, by Augustine, ed. S. Poque, Sources chrétiennes 116 (Paris: CERF, 2011), 210-21; Augustine, "Sermo 121, Tractatus sancti Augustini de sanctissiame Paschae die prima," in Sermons pour la Pâque, by Augustine, ed. S. Poque, Sources chrétiennes 116 (Paris: CERF, 2011), 222-33.

23. Van Oort, "The End Is Now." 
the knowledge of the Old Testament and the culture of Egypt that might have been preserved in the oral traditio, inscriptions or written record, had this concept of "today" and of the short time of the Lunar calendar in his veins. This statement, at this moment a hypothesis, will later be shown to be based on the solid foundation of his own unusual imagery of the Apocalypse that scholars had ignored and only recently discussed as meaningful part of his approach of the difficult problem of how to explain the flourishing and expansion of the Christian and Judeo-Christian community at the time of the presumed end and of the coming of the "Millenial Kingdom."24 Let us look in his works for the ideas that relate to his solution of interpreting the construction of the Christian community and the church at the time when, at about $400 \mathrm{CE}$, there might have been only about a century left to the end of 6000 thousand years from the Creation and the coming of the end of times. ${ }^{25}$ The Egyptian calendar was not only that of the precise time reckoning based on the flooding of the Nile, it also knew the precise everyday cycle of a Lunar month as a sequence of day-by-day marks. ${ }^{26}$

Augustine's representations of the eschatological ideas that had found their form in the Old Testament were not one-dimensional. Using these ideas he was "moulding the present", as it has been suggested..$^{27}$ In fact, his approach to them was different than that of Jerome who had designated Rome as the fourth Empire that in the terms of the Book of Daniel was also to fall with the first three ones. In fact, addressing the idea of the end of times Augustine was able to define the path for the development of the Christian community within the Roman Empire at his time and at same time to separate and distance from the history of the church the past of those civilizations that Christian thinkers deemed as dead ends in history..$^{28}$

24. Landes, "The Silenced Millenium," 169-72.

25. Art. Era, In The Schaff-Herzog Encyclopedia of Religious Knowledge, edited by Rev. Philip Schaff, vol 4 (New York, 1908-1913), 163. Elias J. Bickerma, Chronology of the Ancient World, 2nd edition (Ithaca, NY: Cornell University Press, 1980), 73.

26. Richard Anthony Parker, The Calendars of Ancient Egypt, Studies in Ancient Oriental Civilization 26 (Chicago: University of Chicago Press, 1950), 11-12.

27. Karla Pollmann, "Moulding the present: apocalyptic as hermeneutics in City of God 21-22," in Augustine and Apocalyptic and the Fall of Rome: Augustine and the Year 6000, ed. John Doody, Kari Kloos, and Kim Paffenroth (Lanham: Lexington Books, 2014) (Reprint of Karla Pollmann, "Moulding the present: apocalyptic as hermeneutics in City of God 21-22," Augustinian Studies 30:2 (1999): 165-181.

28. Richard Corradini, "Die Ankunft der Zukunft. Babylon, Jerusalem und Rom als Modelle von Aneignung und Entfremdung bei Augustinus" ["The arrival of the future. Babylon, Jerusalem, and Rome as Models of Appropriation and Alienation by Augustine"], in Strategies of Identification: Ethnicity and Religion in Early Medieval Europe, ed. Walter Pohl and Gerda Heydemann, Cultural Encounters in Late Antiquity and the Middle Ages 13 (Turnhout, 2013), 65-142. 
The problem of investigating the Apocalypse is rooted in the plurality of this concept that in one way or another existed in all civilizations. It received a particularly widespread representation in the texts one finds in Egypt and the near East, but the idea was not limited to only one text like the Bible or only one historical period of Near Eastern history. Thus when investigating the development of thought on this topic by Jerome, Tyconius and Augustine one may need to be aware that they not only dealt with a difficult topic with many adjunct themes, but also with a tradition of communication on this theme between the educated representatives of different human collectives. Thus they were dealing, even in the case of the Bible, less with a singular text, whose authors shared the same worldview, but more with a quite opposite phenomenon. To grasp the difficulty of the material they were addressing one thus needs to take into account the process whereby the knowledge on this touchy theme was extracted from the texts, understood and construed as a narrative for people unrelated to the project of keeping sacred history on track. This requires of the modern scholar to resolve several problems: first, to understand how the concept of the beginning and the end of history was first incorporated into one text, second, to investigate the practice of communicating between the general, "localized" and "the other" traditions of viewing this phenomenon, and third to study the ways in which the knowledge of the Apocalyptic tradition in its most educated and arcane format was read into a single coherent and explanatory narrative outside of the sphere of the sacred knowledge, say, in a parable.

But how one can separate and distinguish the contributions of such different authors as Jerome and Augustine who could both claim an unprecedented and critical role in constructing the Christian concept of universal history? In fact, Jerome can be claimed to have the singular importance as the scholar who made the mainstream Christian community aware of the ways to make the Old Testament prophetic texts part of the New Testament reader's learned apparatus. He laid the foundation for this process as he pointed out to the main text that constructed an eschatological worldview, the Book of Daniel, and managed to capture one critical idea of eschatology, that of the possibility to employ the framework in regards to several cultures of the same type and to transfer the predications of the old text to the situation the Mediterranean experienced in the fourth and fifth centuries CE. ${ }^{29}$ In this treatise Jerome sought and largely managed to resolve the issue of the relevance the eschatological scheme of history of the chosen

29. Hieronymus, "S. Eusebii Hieronymi Stridonensis presbyteri Commentariorum in Danielem Prophetam ad Pammachium et Marcellam Liber" ["Notes on Daniel S. Hieronymi Stridoniensis Priest Prophet Pammachius and Marcella book"] in PL, 25(n.d.), col. 491-584; Lawrence T. Martin, "Art. Daniel," in A Dictionary of Biblical Tradition in English Literature, ed. David Lyle Jeffrey (Grand Rapids, MI: Wm. B. Eerdmans, 1992), 177-80. 
people to the Late Roman world he was implying. ${ }^{30}$ His approach was more descriptive and less analytical than one may imagine because he did not venture into disassembling the narrative and imagery into their constituent pieces. Even more so, he did not seek to comprehend any mathematics that had possibly been incorporated into the Old Testament texts on both the literal and figurative level. Thus Jerome's treatise and take on the Book of Daniel were a very significant attempt at grasping, in the Roman context and from the perspective of a person interested and knowledgeable in Roman history, the complex world of the near eastern narratives of the foundation of the community of the chosen people. Augustine's critical treatise was on the cities which addressed exactly this question. But did he propose in this particular context any idea that could help the readers transform text into a tool of leaning and understanding? How did Augustine compare to Jerome and was there anything significant in the terms of the practical questions of examining the apocalyptic representation of history? In other words, how did Augustine connect the sacred history to his own day other than propose that all empires, including the Roman empire, will eventually give way to the universal community of those who believed in the prediction given in the Old and New Testaments?

The difficulty of understanding and developing one's own concept of the Old Testament's historical time lay in the fact that it had been formed by the people who were well-versed in the complex forms of representing reality and the historical past in the myth-creating texts, such ones that sought to establish in the past a common foundation for the community in the present. In other words, the authors of the books of the Old Testament had been brought up on the whole array of various texts and scribal exercises. One may thus take into account the fact that those methods scholars sometimes called as "literary approaches" were not only well-known to them, but in fact were incorporated into their process of education from very early on in their careers. Thus any piece of text in the Old Testament was written in light of the three factors. These were the general historical framework, in this case that of the chosen people, the available myths and legends in the form of a written document or oral tradition, but also, much underappreciated practices of combinatorics in letter and number usage. After all, the scribes who were writing the Old Testament lived in the world where due to the strong Egyptian influences the calendar had reached a significant development. ${ }^{31}$ These were, as it was shown, known to Hypparchus, astronomer and mathematician of the second

30. Archer, Jerome's Commentary on Daniel; Jay Braverman, Jerome's Commentary on Daniel: A Study of Comparative Jewish and Christian Interpretations of the Hebrew Bible, Catholic Biblical Quarterly Monograph Series 7 (Washington, 1978).

31. Parker, The Calendars of Ancient Egypt, 11-12. 
century BCE. ${ }^{32}$ One needs to appreciate that the educated people in the near East were growing up with learning aids such as alphabets, practice exercises in mathematics and other skills of literacy and, what is more important, board-games that taught spatial orientation, combinatorics and the ability to construct a game, that is, a narrative..$^{33}$ The royal game of Ur was a phenomenon that was located at the juncture of the history of kings, their stories, and perhaps, the astronomical phenomena. ${ }^{34}$ They had complex rules that required knowledge of the signs on the board and of the steps to be made. ${ }^{35}$ The notion of a boardgame is important here because it allows one to consider how the timeframes were constructed out of blocks, segments and bits and thus lets us reconsider this critical contribution that Augustine made to the Christian calendar by constructing a "bridge" between the long-term epochs of the Creation and the actual time of living in the Roman Empire of the early 400s. The texts that Augustine read, the Old Testament as well as many others, could have possessed this level of complexity in representing time and so one may need to consider his as more of a specialist in combinatorics than a pure "person of the narrative". Thus at least on the level of possibility one needs to evaluate the importance of these traditional tidbits of time reckoning for the construction of the skills of literacy necessary for writing sacred texts and, among them, the texts of the books of the Old Testament.

\section{"Social time", Divine Retribution and Sacrifice}

One needs to take these singular events in Augustine's life through the prism of his whole life and the longer cycles that governed traditional society. But these are the events that many if not most of the people go through in their lives. The Old Testament calendar was constructed, however, in much longer cycles as the coming of Christ was believed to fall on either the year ca. 5500, or the year ca. 5199 or 3952 from the Creation. ${ }^{36}$ The critical question was how to connect one

32. Fabio Acerbi, "On the shoulders of Hypparchus: A reappraisal of ancient Greek combinatorics," Archive for the History of Exact Sciences 57(2003): 465-502.

33. Leonard C. Woolley, The Development of Sumerian Art (New York: Scribner's, 1935), Pl. 35.

34. Andrea Becker, "The Royal Game of Ur," in Ancient Board Games in Perspective: Papers from the 1990 British Museum Colloquium, with Additional Contributions, ed. Irving Finkel (London, England: British Museum Press, 2007), 11-15.

35. Irving L. Finkel, "On the rules for the royal game of Ur," in Ancient Board Games in Perspective: Papers from the 1990 British Museum Colloquium, with Additional Contributions, ed. Irving Finkel (London, England: British Museum Press, 2007), 16-32.

36. Art. Era, In The Schaff-Herzog Encyclopedia of Religious Knowledge, vol. 4 (New York, 1908-1913), 163. Bickerman, Chronology of the Ancient World, 73. 
life's experiences to this longer cycles of at least a hundred or several hundred years. In addition to the basic cycle of life: birth, death and the coming of the new generation, there is a much darker cycle of transgressing the boundary and the divine retribution for the offense, which in historical narrative usually takes the for of warfare and/or revenge. The simplest example, which had found widespread acceptance as the meaningful concept of history, is the story of Gyges and Candaules that Herodotus placed in the opening chapters of his book. The divine retribution for the murder of Candaules came on the fifth generation from Gyges who lost his kingdom to the Persian empire, which paradoxically became in this case a tool of divine judgment. ${ }^{37}$ The didactic message of Herodotus in this case needs not be questioned since he was the scholar who constructed his history to set boundaries and highlight the positive behavior while distancing the cases not worth to be included in the nominal social practices. ${ }^{38}$

Key to understanding eschatological concepts lies in the fact that they are based on a very specific premise, the exemplification of which we often find in the stories of violent acquisition of power and in the forceful replacement of dynasties, especially of the father-son succession. The beginning and the end of times were a natural concept for every community, but one needs to be aware that communities had their own symbolic means and narratives to convey this idea. Moreover, these narratives were arranged around long-term cycles that determined these communities' existence over centuries and the specific format of a social marker, a story with its own narrative canon. The stories of Cyrus and many other rulers suggested that in the common narrative the end of time and the beginning of time was associated with abnormalities in succession, and such which left the family at the brink of extinction. One may notice that in the "Confessions", which were deeply autobiographical, Augustine did show several times the episodes that served as the connection between the larger frame of his life and the particular episodes in it that served as turning points. Thus one of the critical episodes in my opinion was his attitude to the problem of father-son relationship that figures in his work in a very profound way. In Book II he seems to break a relationship with his father noticing the latter's joy at seeing his adolescence at 16 years of age. His ironic tone shows that he did not accept his parent's hopes of seeing his son as the continuator of his line. Augustine distanced his father, claiming him to have only become a catechumen recently (nam ille adhuc catechumenus et hoc recens erat), and rejoiced at his mother in charge in family as a true Christian (sed matris in pectore iam inchoaveras templum tuum et exordium sanctae habitationis tuae). ${ }^{39}$ This stringent assessment came in contrast to

37. Herodotus, History, ed. Alfred D. Godley, Loeb Classical Library 117 (London, 1990), I, 7-54, 86-91.

38. Lisa Irene Hau, Moral History from Herodotus to Diodorus Siculus (Edinburgh: Edinburgh University Press, 2016), 172-93.

39. Augustine, S. Aurelii Augustini Confessiones (Oxonii [Oxford]: J. Parker, 1872), II, 3, 6. 
the benefits his father lavished on him while providing for the education in a distant land. ${ }^{40}$ This episode may be considered more important than it seems because his father disappears from the book after this notice and is never mentioned again. The explanation Augustine provided cited belonging to the church as the key element of any education his father had misunderstood. ${ }^{41}$ Augustine saw only one model for father-son relationship in the deeds of Old Testament patriarchs, who by their "vision" both in the physical and heavenly sense guided their sons through the bottlenecks of the history of the chosen people. ${ }^{42}$ His father became subject to a ritual removal of his father from his life (or even, in the sense of Oedipus Rex of Aeschylus, the ritual imaginary killing) when he himself became adolescent. Thus, at least at face value, the male line of succession was to end at Augustine's accession, perhaps subliminal and unconscious at first, to the church of his mother. This is all the more strange since in traditional society of Rome and of the Old Testament the patrilineal descent was critical and the format of father-son relationship was considered as one of the first means identification within community.

The importance of the father-son problem in Augustine's "Confessions" is evident. Augustine cited as the beginning of his independent life and of the path to Christianity the cutting off of the ties to his father. He became the "child of God's provenance", but his earthly father disappeared from his life and biography altogether despite all good deeds he made for his son. The coming to Christianity coincided for him with the loss of his own son from the first concubine to a disease, Adeodatus. Thus in his own life he himself "sacrificed", at least in his mind and world, his father to become an independent adult in his own train of life. By his life even before he had become Christian Augustine lived through the events that in the world of the Old Testament narrative would have been considered Apocalyptic. And in turn, he went through a sacrifice himself when his son passed away.

One may notice that the theme of the son sacrifice was a critical one for the story of the chosen people and of Jacob who was thus elected to pass through this morally problematic, but common to the Old Testament "bottleneck". Rulers of the Ancient World possessed various functions that were aimed at protecting communities from the vagaries of the environment and the "bottlenecks" of society's cycles of development. "The Golden Bough" of J. Fraser, first published in the 1890 in two volumes, suggested that rulers possessed a double role, both that of a winner in control and also a sacrifice to Gods in case a collective faced challenges it could not resolve. His work was significant in emphasizing that to every successful rule there was always deemed to be an end that was to obliterate this ruler's achievement. The idea of human sacrifice as a payment to avoid

40. Ibid., II, 3,5 .

41. Ibid., II, 3, 5 .

42. Ibid., X, 34, 52. 
expected retribution from divine forces or from other human collectives for the unjustified acts of violence in the past was noticed by scholars, but is usually passed over as both a basic tenet of historical research and the theme too horrid to be discussed. The killing of the Khazar kings was noticed by J. Fraser. ${ }^{43}$ The ritual of killing a pseudo-king, at the beginning if the New Year in Mesopotamia, was noticed by scholars. ${ }^{44}$ This was founded on the ultimate belief in traditional societies that "lying kings" who betray their people exist and are common. ${ }^{45}$ Thus sacrifice, or the attempted sacrifice of the ruler was not only a biblical theme since the death of Hektor at the hands of Achilles, or the early death of Alexander the Great, or even in some sense the theme of Julius Caesar were also in the same line of stories.

The problem of the son of a man with status and his sacrifice or botched succession has direct relevance to the theme of ruler sacrifice, even though the first brings in an expectation of family succession, natural for every human collective. In fact, they are typologically similar. In fact, the ritual "sacrifice" of one's father for advance in life is key to understanding Augustine. It remained ritual, which is natural for many rituals of "coming of age." A young heir to his father's power, lineage or fortune "sacrificed" by one's will, by the will of God, or by the conjunction of factors at an inopportune moment to the divine forces was also a symbol of restoring the balance of justice with the divine and the humans, the neighbors. Can one call these events a "personal Apocalypse" for community, and in the case of Augustine, one for his father and for himself? The killing of the old ruler was the end of the cycle of violence and the beginning of the new era of reconciliation. It is attested in the case of Mesopotamia since this ritual was associated with the coming of the new year and hence, of the short "new era." If not so, they could be at least measured against the "grand" Apocalypse that was predicted by the Old Testament and New Testament narratives. Augustine leaving his father without much communication to him ended one cycle that might have earlier brought his parent to the top of his social ladder and made him a person of such stature that his son could easily study in the best schools of Africa. Augustine's losing his own son from a concubine meant the end not only for his own dissolute life, or at least the life which he sought to represent in this way, but it meant the end of his "struggles with God" in the field of rational theology.

43. James George Frazer, "The Killing of the Khazar Kings," Folk-Lore xxviii (1917): 382-407.

44. Heinrich Zimmern, Zum babylonischen Neujahrsfest (Leipzig, 1918).

45. Beate Pongratz-Leisten, "'Lying King' and 'False Prophet': The intercultural transfer of a rhetorical device within ancient eastern ideologies," in Ideologies as Intercultural Phenomena: Proceedings of the Third Annual Symposium of the Assyrian and Babylonian Intellectual Heritage Project, Chicago USA, Oct. 27-31, 2000, ed. Antonio Panaino and Giovanni Pettinato (Milan: Univestita di Bologna \& islao, 2002), 215-43. 
Critical for the theme of ending and beginning the cycle was the father-son passing of legitimacy, status and authority. Giving a son the possibility to continue in the footsteps of his father was that point of comparison and reference that allowed any person, and not just an educated one, to measure the cycle of life and to check his life against any pending offsets due to the divine retribution or a positive interference of divine grace. Thus history found its representation in the minds of the people from traditional society in the form of a generation change and the ways to assess it. The themes of the first-born son and of the sacrifice of a son were the means to suggest where the people constructing the story were located in terms of the history of a society or culture. One may notice, therefore, that the theme of the father-son relationship was widespread and modern scholars should seek to find it not only in the Bible, but also other texts of different provenance and cultural practice of unexpected nature. But one needs to look first at those cases that people of traditional society believed to be the beginning and the turning point and particularly, the end of the cycle. Only stories in which the passing of authority from the father to son broke down and failed to become realized may be considered as those that define the new beginning both within one's individual life and in the life of a collective. Thus critical for determining the beginning and end of a cycle was the theme of a sacrifice that could end the cycle of retribution.

One may notice that in terms of the length of time the seven generations that had to be avenged lasted about one hundred and fifty years if one takes as a measure of generation a period of about twenty years. After the seventh generation started, the divine judgment was right on the heels of the dynasty and was affecting the last king from the line of Gyges directly. Herodotus was the first among historians of the Mediterranean who invoked the theme of the divine retribution and among his followers were such important historians as Gregory of Tours, who no doubt employed the idea as it was transformed in the context of forming the Christian concept of history. Thus the innate biological calendar was working within communities and the only difference in our understanding of them was in the fact that their idea of the generations waiting for the retribution was more pronounced in some than in others. Thus humans living in traditional societies need not be left out of knowing the long-term processes of history. The cycles of history were visible within several generations on the basic level of human self-identification. For example, Romans did not lose a chance to cite, as did Marcus Aurelius, their grandfathers to emphasize their kin was blessed by the divine. Thus the idea of the cycles, both beneficent and malevolent, in lives of families was inherent for all human collectives and existed outside the discourse of history as such. Augustine, describing the linear development of his live, which no doubt was circular if we look at him from a lengthier perspective of scholars knowing similar cases, was an example of how in Mediterranean society the "course of life" was a basic tenet that appealed to all people regardless of the form in which belief in divinity was shaped. But this cycle of individual life was 
interspersed with cycles that needed to be given closure, whether they were good or bad.

\section{Conclusion}

Augustine's writings provide ample evidence that many sacred themes from the Ancient world were reshaped in the Christian context without losing their chief characteristics. The calendars of the sacred texts that were constructed around the periods of longue durée required periodical re-setting, which was achieved by means of certain narratives, like those of the sacrifice of a ruler or a son. But unlike in the narrative of the Book of Job, Augustine's "Confessions" ended up without a "voice from the sky" that restored all to its pristine status. The end of a historical period of a sacred narrative, if not marked by reconciliation and submission, was accompanied by a break in a patrilineal succession in Augustine's life, or at least was perceived in this way. Thus one needs to pay closer attention to the break in cycles not only in the Bible, but also in the texts produced by nearby cultures where this connection of a sacrifice of a son serves as a payment to settle the scores of divine retribution. The personal "Incarnation" as an adult was followed in the life of Augustine by the "Apocalypse" of personal loss and of the destruction of many structures in which Augustine believed. One need not think that life in the late fourth- and the early fifth-century Mediterranean did not allow for people to see the signs of the "End of Times" in their lives. People who were turning to Christianity lived in a world where the expectation of the divine judgement within the family carried both positive and negative connotations for family traditions that had originated several generations back and that determined the present for their members. Thus, the break in the father-son relationship was for Augustine, much as the Old Testament patriarchs, the moment for re-setting the time. The Apocalypse, about which Augustine was writing, was right next to everyone's life. It is no wonder that writing two centuries later, Gregory of Tours, while developing the ideas of Augustine, emphasized the immanent presence of the destructive events of the divine retribution even in the best of days as calculated according to the biblical calendar. ${ }^{46}$ We can attribute this idea of the bishop of Tours to the bishop of Hippo's extensive and forceful writings. Augustine was thus the person who set for the Middle Ages the idea of the immanent co-existence within one historical time, within one's life and the personal events in it, and within one historical narrative, of both the long-term grace and the short-term apocalypse.

46. Gregorius Turonensis, "Libri Historiarum X," in Gregorii episcopi Toronensis Libri Historiarum X, ed. Bruno Krusch and Wilhelm Levison, 2nd ed., vol. 1.1, MGH Scriptores Rerum Merovingicarum (Hannover: Hahn, 1951), Lib. II, Praef. 


\section{Bibliography}

Acerbi, Fabio. "On the shoulders of Hypparchus: A reappraisal of ancient Greek combinatorics." Archive for the History of Exact Sciences 57 (2003): 465-502.

Archer, Gleason L. Jerome's Commentary on Daniel. Edited and translated by Gleason L. Archer. Eugene, Oregon: Wipf; Stock, 2009.

Augustine. "Confessiones." Edited by J. J. O’Donnell. Oxford: Clarendon Press, 1992.

. S. Aurelii Augustini Confessiones. Oxonii [Oxford]: J. Parker, 1872.

"Sermo 121, Tractatus sancti Augustini de sanctissiame Paschae die prima." [121 word Treaty sanctissiame St Augustine, the first day of Passover]". In Sermons pour la Pâque, by Augustine, 222-33. Edited by S. Poque. Sources chrétiennes 116. Paris: CERF, 2011.

. "Tractatus de nocte sancta." In Sermons pour la Pâque, by Augustine. Edited by S. Poque. Sources chrétiennes 116. Paris: CERF, 2011.

Becker, Andrea. "The royal game of Ur." In Ancient Board Games in Perspective: Papers from the 1990 British Museum Colloquium, with Additional Contributions, edited by Irving Finkel. London, England: British Museum Press, 2007.

Bischoff, Bernhard, and Michael M. Gorman. Manuscripts and Libraries in the Age of Charlemagne. Cambridge: New York: Cambridge University Press, 1994.

Braverman, Jay. Jerome's Commentary on Daniel: A Study of Comparative Jewish and Christian Interpretations of the Hebrew Bible. Catholic Biblical Quarterly Monograph Series 7. Washington, 1978.

Corradini, Richard. "Augustine's eschaton: Back to the Future." In Abendländische Apokalyptik. Kompendium zur Genealogie der Endzeit, edited by Veronika Wieser, Christian Zolles, Catherine Feik, Martin Zolles, and Leopold Schlöndorff, Kulturgeschichte der Apokalyptik 1. Berlin: Akademie Verlag Berlin, 2013.

"Die ankunft der zukunft. Babylon, Jerusalem Und Rom Als Modelle von Aneignung Und Entfremdung Bei Augustinus" ["The arrival of the future. Babylon, Jerusalem, and Rome as Models of Appropriation and Alienation by Augustine"]. In Strategies of Identification: Ethnicity and Religion in Early Medieval Europe, edited by Walter Pohl and Gerda Heydemann, Cultural Encounters in Late Antiquity and the Middle Ages 13. Turnhout, 2013.

Finkel, Irving L. "On the rules for the royal game of Ur." In Ancient Board Games in Perspective: Papers from the 1990 British Museum Colloquium, with Additional Contributions, edited by Irving Finkel. London, England: British Museum Press, 2007.

Frazer, James George. "The Killing of the Khazar Kings." Folk-Lore xxviii (1917): 382-407. 
Grabbe, Lester L. "A Daniel for All Seasons." In The Book of Daniel: Composition and Reception, edited by John J. Collins, Peter W. Flint, and Cameron VanEpps. Leiden: Brill, 2002.

Gregorius Turonensis. "Libri Historiarum X." In Gregorii episcopi Tvronensis Libri Historiarum X, edited by Bruno Krusch and Wilhelm Levison, 2nd ed. Vol. 1.1. MGH Scriptores Rerum Merovingicarum. Hannover: Hahn, 1951.

Hau, Lisa Irene. Moral History from Herodotus to Diodorus Siculus. Edinburgh: Edinburgh University Press, 2016.

Herodotus. History. Edited by Alfred D. Godley. Loeb Classical Library 117. (London, 1990).

Hieronymus. "S. Eusebii Hieronymi Stridonensis presbyteri Commentariorum in Danielem Prophetam ad Pammachium et Marcellam Liber" ["Notes on Daniel S. Hieronymi Stridoniensis Priest Prophet Pammachius and Marcella book"]. In PL, 25(n.d):491-584.

Jong, Mayke de. "The Empire as Ecclesia: Hrabanus Maurus and biblical historia for rulers." In The Uses of the Past in the Early Middle Ages, edited by Yitzhak Hen and Matthew Innes. Cambridge: Cambridge University Press. 2000.

Landes, Richard. "The Silenced Millenium and the Fall of Rome: Augustine and the Year 6000 Am I." In Augustine and Apocalyptic and the Fall of Rome: Augustine and the Year 6000, edited by John Doody, Kari Kloos, and Kim Paffenroth. Lanham: Lexington Books, 2014.

Markus, Robert Austin. Saeculum: History and society in the theology of St Augustine. Cambridge: Cambridge University Press, 1970.

Martin, Lawrence T. "Art. Daniel." In A Dictionary of Biblical Tradition in English Literature, edited by David Lyle Jeffrey, 177-80. Grand Rapids, MI: Wm. B. Eerdmans, 1992.

McGinn, Bernard. Visions of the End: Apocalyptic Traditions in the Middle Ages. Records of Civlizations 96. New York, NY: Columbia University Press, 1979.

Momigliano, Arnaldo. "Pagan and Christian historiography in the forth century A.D." In Essays in Ancient and Modern Historiography, edited by Arnaldo Momigliano. Middletown, Conn.: Wesleyan University Press, 1977.

Parker, Richard Anthony. The Calendars of Ancient Egypt. Studies in Ancient Oriental Civilization 26. Chicago: University of Chicago Press, 1950.

Perrin, Norman, and Dennis C. Duling. The New Testament: An Introduction, Proclamation and Parenesis, Myth and History. San Diego: Harcourt Brace Jovanovich, 1974.

Pollmann, Karla. "Moulding the present: Apocalyptic as hermeneutics in City of God 21-22." In Augustine and Apocalyptic and the Fall of Rome: Augustine and the Year 6000, edited by John Doody, Kari Kloos, and Kim Paffenroth, Lanham: Lexington Books, 2014.

Pongratz-Leisten, Beate. "' Lying King' and ' False Prophet' : The intercultural transfer of a rhetorical device within ancient eastern ideologies." In Ideologies as Intercultural Phenomena: Proceedings of the Third Annual Symposium of the 
Assyrian and Babylonian Intellectual Heritage Project, Chicago USA, Oct. 27-31, 2000, edited by Antonio Panaino and Giovanni Pettinato. Milan: Univestita di Bologna \& Islao, 2002.

Rapp, Claudia. Holy Bishops in Late Antiquity: The Nature of Christian Leadership in an Age of Transition. Transformation of the Classical Heritage 37. Berkeley: University of California Press, 2013.

Van Oort, Johannes. "The end is now: Augustine on history and eschatology." HTS Teologiese Studies/Theological Studies 68, no.1 (2012): Art. \#1188.

Woolley, C. Leonard. The Development of Sumerian Art. New York: Scribner's, 1935.

Zimmern, Heinrich. Zum babylonischen Neujahrsfest. Leipzig, 1918. 